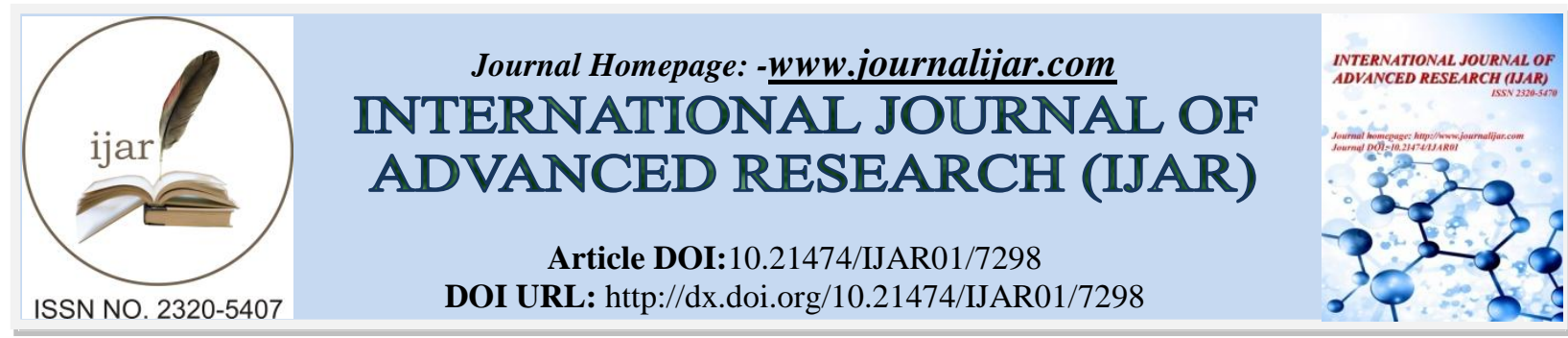

RESEARCH ARTICLE

\title{
PREVALENCE OF VIRAL HEPATITIS AB AND C INFECTIONS AND ITS ASSESSMENT ON SELECTED PRIMARY HEALTH CARE CLINICS IN TARABA STATE, NIGERIA.
}

\author{
Ihedigbo, P.O., Gberikon, G.M., Aondoackaa, A.D
}

University of Agriculture Makurdi, Benue state.

\section{Manuscript Info}

Manuscript History

Received: 16 April 2018

Final Accepted: 18 May 2018

Published: June 2018

Keywords:-

Viral hepatitis, TarabaState, Prevalence, Healthcare

\begin{abstract}
Prevalence of Viral Hepatitis ABC Infection and its Assessment on Selected Primary Health Care clinics in Taraba state was investigated. Blood Samples were aseptically collected from 383 consented individuals. Sera were assayed for Hepatitis A, Hepatitis B and Hepatitis $\mathrm{C}$ antibodies. Rapid qualitative screening method for the detection of viral markers in the blood samples specific to each type of hepatitis virus was employed. Each serum was tested for antibodies to Hepatitis A virus total antibody using Micro point One- step rapid Test Kit for screening Hepatitis A virus antibody and both hepatitis B surface antigen and anti-N U hepatitis $\mathrm{C}$ antibody were screened using Egens Rapid Diagnostic test Kit and rapid qualitative diagnostic tests method to screen for Hepatitis A, B and C viruses by the detection of viral markers in the blood samples specific to each type of hepatitis virus. Risk factors relating to hepatitis were obtained using a questionnaire. A total of $6(1.6 \%), 31(8.1 \%)$ and $42(11.0 \%)$ subjects were seropositive for Hepatitis A virus, Hepatitis B virus and Hepatitis $\mathrm{C}$ virus respectively. The prevalence co-infection of Hepatitis A /Hepatitis B virus and Hepatitis B /Hepatitis C virus were 1(0.3\%) and $3(0.8 \%)$ respectively. The result revealed that Taraba State is burdened with hepatitis infection with overall prevalence of $20.6 \%$ for the 3 viruses studied. Viral hepatitis A did not show significant statistical association $(\mathrm{P}>0.05)$ with any of the considered variables among the subjects. However seroprevalence of hepatitis B surface antigen differed significantly $(\mathrm{P}<0.05)$ with family size and primary health care clinics used in this work. The study showed that viral Hepatitis C and B are major public health concern in this study area and prevalence for both viruses can be considered high. Thus, it is suggested that emphasis on the importance of awareness, routine screening, immunization (for both child and adult) and antiviral therapy should be provided in the State.
\end{abstract}




\section{Introduction:-}

Hepatitis is an infection that causes inflammation of the liver. This condition can be self-limiting by the intervention of one's immune system or can progress to fibrosis (scarring), cirrhosis or liver cancer. Hepatitis viruses (Viral hepatitis) are the most common cause of hepatitis in the world but other infections such as, toxic substances (alcohol, certain drugs such as paracetamol), and autoimmune diseases can also cause hepatitis (WHO, 2016).

Viral Hepatitis may be caused by at least five distinct viruses known as types, A, B, C, D, or E. Each belongs to an entirely different family of viruses and they have very little in common except the target organs. Each Hepatitis virus is distinct with characteristic pattern of transmission, clinical illness and long term complication. These unrelated viruses can produce an acute illness characterized by nausea, malaise, abdominal pain and jaundice. Although most acute infection may be asymptomatic or cause only mild disease, Type B and type C usually become chronic and can progress to cirrhosis or hepatocellular carcinoma (CDC, 2013). Depending on type, viral hepatitis can affect anyone (both children, young and old).The medical impact of these viruses on society has been strongly influenced by changes in human ecology (World Health Organization (WHO), 2013; Abdulbariet al., 2009). Just like other infectious diseases, viral hepatitis have shown a dramatic rise in infectivity in the last twenty years despite the advancement in healthcare services through immunization, provision of modern healthcare facilities, new drugs, and more accuracy in diagnosis (Carballo, 2007). This is because individual human genetic make-up, life-style, physical, socio-cultural crowded housing, and the utilization of healthcare services are the major determinants of the success or otherwise of human infectious diseases including the long-term impact of the infectious germs in human systems (Lawal and Umar, 2015). Hepatitis viruses replicate (multiply) primarily in the liver cells. This can cause the liver to be unable to perform its functions. This has constituted serious public health issues and hence the need to investigate its prevalence among the different types.

\section{Materials AndMethods:-}

\section{Sample population:-}

Samples were collected from patients attending primary health care clinics in three Local Government Areas in Taraba state. Health care clinics includes (Iman, Iware, Lankaviri, Manang, Santali, Jolly Nyame, Pupule, TurakiModel,Wuro-Yolde) that has laboratory facilities attached to them. Patients were sampled on the clinical days of the primary health care clinics when a good number of patients will come for health care services. Volunteer participants who gave informed consent were included in this study after a brief health talk on Hepatitis during their routine health education.

\section{Sample size:-}

Raosoft Sample Size Calculator was used to determine the sample size (Raosoft, 2011).A total of 384 participants were recruited in this study.

\section{Sample Collection:-}

Three $(3 \mathrm{ml})$ milliliters of blood were aseptically collected by venipuncture using syringe and needle from each participant and discharged into a vacutainer by a laboratory technician. The blood specimens were transferred into well labeled test tubes with serial number tags and was allowed to clot or centrifuged at $1000 \mathrm{~g}$ for 5 minutes to separate the serum from the whole blood. Serum was aspirated with Pasteur pipette and was used immediately for the test. The screening was carried out in the laboratory unit attached to the PHCC where the samples were collected.

\section{Laboratory Analysis:-}

All sera were assayed for Hepatitis A, Hepatitis B and Hepatitis C antibodies. Rapid qualitative screening method for the detection of viral markers in the blood samples specific to each type of hepatitis virus was employed. Thus each serum was tested for antibodies to Hepatitis A virus total antibody using Micropoint (USA) One- step rapid Test Kit for screening Hepatitis A virus antibody and both hepatitis B surface antigen and anti-N U hepatitis C antibody were screened using Egens Rapid Diagnostic test Kit (USA).The test procedure was followed according to the manufacturer's instructions.

\section{Interpretation of Results:-}

The test required the use of "test strips" that provides results in approximately 20 minutes. (Food and Drug Administration (FDA), (2010). Positive screening was determined by the appearance of two red bars in both the 
control and the patient's window strip. The occurrence of only one red bar on the control strip indicated negative screening test. While no red appearance on the control bar or test showed invalid result, which has to be repeated for that sample using a new test strip? Point to note: the intensity of the red colour in the bar (line) region varies depending on the concentration of the viral marker present in the specimen. Thus any shade of red bar in the test region is considered positive.

\section{Administration of Questionnaires:-}

Questionnaires were provided for every volunteer in English for the educated and local dialects (through interpreters) for the illiterate rural dweller through personal one on one or small group discussions.

\section{Results And Discussion;-}

Table 1:-Prevalence of Hepatitis A, B and C among Patients Attending Selected Primary Health Care Clinics in Taraba State

\begin{tabular}{|l|c|lc|l|}
\hline & Total No Examined & \multicolumn{2}{|c|}{ No Positive (\%) } & No Negative (\%) \\
\hline HAV & 383 & 6 & $(1.6)$ & $377(98.4)$ \\
\hline HBV & 383 & 31 & $(8.1)$ & $352(91.9)$ \\
\hline HCV & 383 & $42 \quad(11.0)$ & $341(89.0)$ \\
\hline
\end{tabular}

KEY: HAV = Hepatitis A Virus, HBV = Hepatitis B Virus, HCV = Hepatitis C Virus, SE =

Standard Error, No + VE $=\quad$ Number of Positive, $(\%)=$ Percentage , No - VE $=$ Number of Negative

Table 2:-Prevalence of Viral Hepatitis A B C in Relation to Patients Attending Selected Health Centers.

\begin{tabular}{|l|l|l|l|l|}
\hline Clinics & No Examined & $\begin{array}{l}\text { HAV } \\
\text { Positive. }(\%)\end{array}$ & $\begin{array}{l}\text { HBV } \\
\text { Positive. }(\%)\end{array}$ & $\begin{array}{l}\text { HCV } \\
\text { Positive. }(\%)\end{array}$ \\
\hline Imam & 42 & $0(0.0)$ & $8(19.0)$ & $6(14.3)$ \\
\hline Iware & 43 & $1(2.3)$ & $5(11.6)$ & $2(4.7)$ \\
\hline Lankaviri & 43 & $0(0.0)$ & $3(7.0)$ & $5(11.6)$ \\
\hline Manang & 42 & $1(2.4)$ & $6(14.3)$ & $5(11.6)$ \\
\hline Santali & 43 & $0(0.0)$ & $3(7.0)$ & $3(7.0)$ \\
\hline Jolly Nyame & 43 & $1(2.3)$ & $0(0.0)$ & $6(14.0)$ \\
\hline Pupule & 43 & $1(2.3)$ & $4(9.3)$ & $9(20.9)$ \\
\hline Turaki Model & 42 & $0(0.0)$ & $1(2.4)$ & $2(4.8)$ \\
\hline Wuro-Yolde & 42 & $2(4.8)$ & $1(2.4)$ & $4(9.5)$ \\
\hline Total & $\mathbf{3 8 3}$ & $6(1.6)$ & $31(8.1)$ & $42(11.0)$ \\
\hline
\end{tabular}

$\mathbf{P}=\mathbf{0 . 6 3 0 . 0 3 0 . 3 0}$

Key:-HAV = Hepatitis A Virus; HBV = Hepatitis B Virus; HCV = Hepatitis C Virus; NO = Number; $(\%)$

Percentage

\section{Discussion:-}

The high prevalence observed in this study and the previous study shows that, these study areas falls within the areas of high levels of infection which is typical of developing counties (like Nigeria and Tanzania) with poor sanitary conditions and hygienic practices (WHO, 2017). The $1.6 \%$ of the patients who were hepatitis A sero-positive is relatively lower than the $5.2 \%$ reported in Calabar by Joanah et al. (2015), $42.5 \%$ observed by Ayoola ( 1982 ) in Ibadan south west Nigeria. The high prevalence from these previous studies suggests that the research was carried out in a riverine environment where much sea foods are consumed by people, such as shellfish which is an important vehicle responsible for transmission of hepatitis A virus (CFS, 2017) and possibly due to lack of public health sanitation which favours exposure in early childhood. This low prevalence of Hepatitis A virus agrees with the $1.5 \%$ reported in Benin (Ogefere and Egbe 2016) and is comparable to the 2.94\% reported in Abuja (Okara, et al., 2017). The lower prevalence in Abuja could be due to the high socioeconomic status of the subjects, improved food hygiene, immunization and greater awareness among the subjects of the studied group. For improvements in hygienic and socio-economic conditions are known factors that decrease in the prevalence of the disease. In this 
study, the location of the Primary Health Care Clinics (PHCC) did not associate significantly $(\mathrm{P}>0.05)$ with hepatitis A virus infection. However the highest infection rate of 9(20.9) HCV was recorded in Pupule clinic located in a rural village. This does not agree with the findings of Hanefi et al. (2009) in Turkey which reported that being a villager was observed as a risk factor for hepatitis A virus infection. The reason for the variation could be based on poor sanitation and low socio economic level of the people. This result is similar to the work of Joanah et al. (2017) in Cross River State who observed prevalence cases in rural hospital setting. This may be that both works were done in Nigeria which is said to be endemic with hepatitis virus (WHO, 2000).

\section{Conclusion:-}

Based on the findings of this study, it was concluded that seroprevalence rates of $1.6 \%$ for hepatitis $\mathrm{A}, 8.1 \%$ for hepatitis $\mathrm{B}$ and $11.0 \%$ for $\mathrm{C}$ virus infections with overall prevalence of $20.6 \%$ among patients attending primary health care clinics in Taraba state. It was established from the findings of this study that, the most common viral hepatitis in the study area is Hepatitis C virus followed by Hepatitis B virus. There is need for public enlightenment on the potential risks and modes of transmission of these viruses and the need to get vaccinated so as to reduce the burden of these diseases among the study area.

\section{References:-}

1. Abdulbari, B., Saad, A., Moutaz, D., Ajayeb, A. and Ammar, R. (2009). The Epidemiology of Viral Hepatitis in Qatar Saudi Journal of Kidney Diseases and Transplantation 20(2):300-306.

2. Carballo, M. (2007).The challenge of migration and health. International Centre for Migration and Health 2007; Geneva.

3. CDC (2013). "Hepatitis A Information for Health Professionals Statistics and

4. Survallance". Centre for Disease Control and Prevention. Retrieved 28 January 2014.Centre for food safety (CFS) (2017). Hepatitis A Virus in shellfish. Food Microbiology.

5. Retrived 3- July- 2017.

6. Food and Drug Administration (FDA). (2010). Approves Rapid Test for Antibodies to Hepatitis C Virus. News and Events. Available at: http://www.fda.gov/NewsEvents/Newsroom/PressAnnouncements/ucm217318.htm

7. Hanefi,C.G., Ismail,Y.A., Omer,C., Recai,O., Yakup,H.B., Cakır,G., Bülent,A.B., Cengiz,H.A.,Can,P. E. and Alaaddin,P. (2009). Turkish Journal of Medical Science, 39(5): 795-802 (C) tübitak e-mail: medsci@tubitak.gov.tr doi:10.3906/sag-0804-10.

8. Joanah, M. I., Henry, C. O., Emmanuel, E. E. and Jacob, J. U. (2015).Seroprevalence and predictors of hepatitis A ifection in Nigerian children. The Pan African Medical Journal, 20:120.

9. Lawal, A. S..and Umar, M. U. (2015). A Geographic Epidemiological Review of Viral Hepatitis B.IOSR Journal of Dental and Medical Sciences 14(12):89-93.www.iosrjournals.orgDOI: 10.9790/0853-141248993.

10. Ogefere, H.O. and Egbe, C.A. (2016). Seroprevalence of IgM antibodies to hepatitis A virus in at - risk group in Benin City, Nigeria. Libyan Journal of Medicine, 11:31290.

11. Okara, G. C., Hassan, S. and Obeagu, E.I. Hepatitis A virus infection among apparently healthy Nigerian Subjects.Journal of Biomedical Science. 2017, 6:2. doi:10.4172/2254 609X.100055.

12. RaosoftEZReport, EZSurvey, InterForm, RapidReport, (2011). Raosoft, and Survey Win, the registered trademarks of Raosoft, Inc. Retrieved from http://www.raosoft.com/on 23/02/2018.

13. World Health Organisation (2000).Hepatitis A. Geneva .World Health Organization. 2000 WHO/CDS/SCR/ EDC/2000. Available at Google Scholar.

14. World Health Organization (2002). Hepatitis Fact sheet No 204 Available: http://www.who.int/mediacentre/factsheets/fs204/en/

15. World Health Organization (2008). Hepatitis A.

16. World Health Organization (2017).Hepatitis B Fact sheet; Fact sheet Number 204:UpdatedMay2015.http://www.who.int/mediacentre/factsheets/fs204/en/

17. World Health Organization (2016). Hepatitis B. assessed 2nd September 2016 from http://www.who.inf/inffs/en/fact204.html.

18. World Health Organization (WHO) (2013). Hepatitis B. Fact sheet Number 204: Updated July 2013 